\title{
Efektivitas Pembelajaran Snowball Throwing terhadap Peningkatan Kemampuan Penalaran Matematis Mahasiwa
}

\author{
Irena Puji Luritawaty \\ Fakultas IImu Terapan dan Sains, Institut Pendidikan Indonesia Garut \\ irenapuji@yahoo.com
}

\begin{abstract}
Abstrak - Latar belakang penelitian ini yaitu pentingnya kemampuan penalaran matematis dalam pembelajaran matematika. Tujuan penelitian ini yaitu untuk mengetahui efektivitas penggunaan pembelajaran model snowball throwing terhadap peningkatan kemampuan penalaran matematis mahasiswa. Metode penelitian ini menggunakan metode pra-eksperimental dengan satu kelompok sampel yaitu kelompok eksperimen yang memperoleh pembelajaran snowball throwing. Adapun desain penelitian berbentuk one group pretest-posttest design, dimana subjek diberikan tes awal (pretest) untuk mengetahui kemampuan awal, kemudian diberi perlakuan selama jangka waktu tertentu, dan diberi tes akhir (posttest) untuk mengetahui pencapaian akhir setelah diberi perlakuan. Populasi dalam penelitian ini yaitu mahasiswa tingkat I di salah satu perguruan tinggi swasta di kabupaten Garut, dengan sampel yaitu mahasiswa kelas IB. Instrumen dalam penelitian ini yaitu berupa tes uraian kemampuan penalaran matematis yang diujikan dalam bentuk pretest dan posttest. Pengolahan data dilakukan terhadap hasil gain ternormalisasi yang diawali dengan uji normlaitas dan diakhiri dengan uji-t satu sampel. Dari hasil penelitian secara garis besar diketahui bahwa penggunaan pembelajaran model snowball throwing sangat efektif meningkatkan kemampuan penalaran matematis mahasiswa (po $\geq 70 \%$ )
\end{abstract}

Kata kunci: Kemampuan Penalaran Matematis, Model pembelajaran Snowball Throwng 


\section{PENDAHULUAN}

Matematika merupakan suatu mata pelajaran wajib di setiap jenjang pendidikan. Di dalam matematika, terdapat beberapa kemampuan yang penting untuk dipelajari, diantaranya yaitu kemampuan pemahaman matematis, pemecahan masalah matematis, koneksi matematis, komunikasi matematis, penalaran matematis, berpikir kritis matematis, dan berpikir kreatif matematis (Hendriana dan Soemarmo, 2014: 32). Adapun tujuan umum pembelajaran matematika yaitu agar: (1) siswa belajar menghargai matematika; (2) siswa membangun kepercayaan diri terhadap kemampuan matematika mereka; (3) siswa menjadi pemecah masalah; (4) siswa belajar berkomunikasi secara matematis; (5) siswa belajar bernalar matematis (Wahyudin, 2008). Tujuan pembelajaran matematika juga dinyatakan oleh BSNP (2006) bahwa salah satu tujuan pembelajaran matematika yaitu agar peserta didik memiliki kemampuan menggunakan penalaran pada pola dan sifat, melakukan manipulasi matematika dalam membuat generalisasi, menyusun bukti atau menjelaskan gagasan dan pernyataan matematis

Salah satu kemampuan dalam matematika dan menjadi tujuan umum dalam pembelajaran matematika yaitu kemampuan penalaran matematis. Penalaran adalah proses berpikir sistematik dan logis untuk memperoleh sebuah simpulan pengetahuan atau keyakinan (Suparno dkk, 2006: 41). Penalaran adalah suatu kegiatan berpikir khusus, di mana terjadi suatu penarikan kesimpulan dari beberapa premis. Kemampuan penalaran dalam matematika dinamakan kemampuan penalaran matematis.

Kemampuan penalaran matematis dapat diartikan sebagai proses berpikir menelaah sesuatu dan diakhiri dengan pengambilan kesimpulan (Andriani dalam Kusmawati, 2013: 11).
Kemampuan penalaran matematis merupakan suatu kebiasaan otak seperti halnya kebiasaan lain yang harus dikembangkan secara konsisten menggunakan berbagai macam konteks. Penalaran dan pembuktian merupakan aspek-aspek fundamental dalam matematika. Dengan penalaran matematis, siswa dapat mengajukan dugaan kemudian menyusun bukti dan melakukan manipulasi terhadap permasalahan matematika serta menarik kesimpulan dengan benar dan tepat (Turmudi, 2008)

Kemampuan penalaran matematis merupakan kemampuan yang sangat penting dalam matematika dan merupakan tujuan utama pembelajaran matematika. Hal tersebut sesuai dengan pernyataan Depdiknas (2003: 6) bahwa tujuan pertama pembelajaran matematika adalah melatih cara berfikir dan bernalar dalam menarik kesimpulan. Ruseffendi (2006) menyatakan bahwa matematika terbentuk sebagai hasil pemikiran manusia yang berhubungan dengan ide, proses dan penalaran. Siswa yang dapat bernalar dengan baik akan mampu berpikir logis dan teliti sehingga pada akhirnya dapat memecahkan suatu masalah dengan benar. Hal tersebut disebabkan karena matematika merupakan pengetahuan tentang penalaran logis dan pengetahuan tentang struktur yang logis (Soedjadi, 2000: 11).

Pentingnya kemampuan penalaran matematis juga dinyatakan oleh Sumarmo (2013) yaitu bahwa kemampuan penalaran matematis sangat penting dalam pemahaman matematis, mengeksplor ide, memperkirakan solusi, dan menerapkan ekspresi matematis dalam konteks matematis yang relevan, serta memahami bahwa matematika itu bermakna. Matematika dan proses penalaran merupakan merupakan dua hal yang tidak dapat dipisahkan. Matematika dapat dipahami melalui proses penalaran, dan penalaran dapat 
dilatih melalui belajar matematika. Pernyataan yang menjadi dasar penarikan suatu kesimpulan dalam penalaran disebut dengan premis atau antesedens, sedangkan suatu pernyataan baru yang merupakan kesimpulan disebut dengan konklusi atau konsekuens (Shadiq, 2004: 2).

Mengingat pentingnya kemampuan penalaran matematis, maka pembelajaran matematika seharusnya dapat memfasilitasi berkembangnya kemampuan tersebut. Salah satu upaya yang dapat dilakukan yaitu dengan merencanakan dan memilih model atau metode pembelajaran yang tepat. Wahyudin (2008) menyatakan bahwa salah satu aspek penting dari perencanaan bertumpu pada kemampuan guru untuk mengantisipasi kebutuhan dan materi-materi atau model-model yang dapat membantu para siswa untuk mencapai tujuan pembelajaran. Hal senada juga diungkapkan oleh Sagala (2011) bahwa guru harus memiliki metode dalam pembelajaran sebagai strategi yang dapat memudahkan peserta didik untuk menguasai ilmu pengetahuan yang diberikan.

Salah satu model pembelajaran yang diperkirakan dapat meningkatkan kemampuan penalaran matematis yaitu model pembelajaran tipe Snowball Throwing yang merupakan salah satu bagian dari model pembelajaran kooperatif dan dapat membuat siswa lebih aktif dalam pembelajaran karena dituntut untuk membuat pertanyaan dan pertanyaan tersebut dilempar ke kelompok lain untuk dikerjakan (Suprijono, 2011).

Snowball Throwing berdasarkan asal katanya terdiri dari snowball yang artinya bola salju dan thorwing yang artinya melempar. Atau secara istilah dapat diartikan sebagai bola salju bergulir. Maksudnya yaitu dalam proses pembelajarannya, digunakan kertas putih yang digulung menyerupai bentuk bola berisi permasalahan atau pertanyaan yang kemudian dilemparkan kepada siswa yang lain, untuk diselesaikan.

Model pembelajaran kooperatif tipe Snowball Throwing dilaksanakan secara berkelompok, dimana guru berperan untuk memantau kegiatan belajar siswa, dan siswa belajar dalam kelompok untuk saling bekerja sama dalam menguasai materi pelajaran (Purbowo dkk, 2012:22).

Proses pembelajaran kooperatif tipe snowball throwing menitikberatkan pusat belajar pada peserta didik. peserta didik aktif berdiskusi dan memecahkan masalah dari pertanyaanpertanyaan yang diungkapkan selama proses pembelajaran serta mengerjakan tugas bersama. Pertanyaan dan jawaban merupakan stimulus dan aktivitas selama proses belajar mengajar (Rasyid \& Side, 2011).

Pelakasanaan model pembelajaran snowball throwing yang diaptasi dari Huda (2011) dapat dilakukan dengan langkah-langkah sebagai berikut:

1. Guru menyampaikan tujuan dan motivasi belajar

2. Guru menyampaikan informasi terkait dengan pembelajaran snowball throwing

3. Guru membagi peserta didik ke dalam beberapa kelompok

4. Guru memanggil ketua kelompok dan menjelaskan tentang materi terkait untuk disampaikan kembali oleh ketua kelompok kepada anggota kelompok

5. Setiap kelompok mulai bekerja dan berdiskusi untuk memahami dan mengembangkan materi yang sudah disampaikan oleh guru, kemudian menuliskan pertanyaan terkait dengan materi tersebut pada selembar kertas. Selanjutnya, kertas tersebut dibuat dalam bentuk bola untuk nantinya dilemparkan kepada kelompok yang lain

6. Setiap kelompok berdiskusi untuk menjawab pertanyaan yang didapatkan, kemudian mencoba mendemonstrasikan hasilnya. 
7. Guru melakukan evaluasi dan menarik kesimpulan.

Berdasarkan langkah-langkah pembelajaran snowball throwing, peserta didik diberi kesempatan untuk berpikir secara teliti guna menganalisis materi dan menyusun konklusinya dalam bentuk pertanyaan. Selanjutnya, peserta didik juga diberi kesempatan untuk memahami materi lainnya dengan baik sehingga dapat memperkirakan perencanaan penyelesaian masalah dari pertanyaan yang didapat dengan benar dan menyusun kesimpulan yang logis berdasarkan informasi yang dimiliki. Kegiatan dalam pembelajaran snowball throwing tersebut tampak menjurus pada pengembangan kemampuan penalaran matematis, dengan indikator yaitu: (1) Mengeksplorasi dan menganalisis situasi matematis, (2) Memperkirakan perencanaan proses pemecahan masalah, (3) Memecahkan persoalan dengan langkah yang sistematis, (4) Menarik kesimpulan yang logis.

Model pembelajaran snowball throwing memiliki beberapa kelebihan, diantaranya yaitu: (1) dapat menciptakan suasana pembelajaran menjadi menyenangkan karena peserta didik dapat belajar sambil bermain melempar untuk relaksasi, (2) Kemampuan peserta didik lebih tereksplorasi karena kemampuan berpikir akan berkembang seiring dengan pertanyaan-pertanyaan yang dibuat dan dijawab (3) Pembelajaran menjadi lebih efektif karena aspek kognitif, afektif, dan psikomotorik dapat dikembangkan selama pembelajaran. Adapun kelemahan model pembelajaran snowball throwing diantaranya yaitu: (1) kesalahan pemilihan ketua kelompok akan berdampak pada pengembangan materi, (2) memerlukan waktu yang relatif lebih lama, (3) sulit mengkondisikan peserta didik pada kegiatan melempar.
Berdasarkan uraian sebelumnya, maka penulis tertarik untuk melakukan penelitian mengenai kemampuan penalaran dan model pembelajaran tipe snowball throwing. Adapun judul yang diambil dalam penelitian ini yaitu Efektivitas Pembelajaran Snowball Throwing terhadap Kemampuan Penalaran Matematis Mahasiswa. Adapun hipotesis dalam penelitian ini yaitu penggunaan pembelajaran model snowball throwing sangat efektif meningkatkan kemampuan penalaran matematis mahasiswa (po $\geq 70 \%$ ).

\section{METODE PENELITIAN}

Metode yang digunkan dalam penelitian ini yaitu metode praeksperimental dengan satu kelompok sampel yaitu kelompok eksperimen yang memperoleh pembelajaran snowball throwing. Adapun desain penelitian berbentuk one group pretestposttest design, dimana subjek diberikan tes awal (pretest) untuk mengetahui kemampuan awal, kemudian diberi perlakuan selama jangka waktu tertentu, dan diberi tes akhir (posttest) untuk mengetahui pencapaian akhir setelah diberi perlakuan. Adapun variabel bebas dalam penelitian ini yaitu pembelajaran snowball throwing, dengan kemampuan penalaran matematis sebagai variabel terikatnya.

Penellitian ini dilakukan di salah satu perguruan tinggi di kabupaten garut, dengan sampel mahasiswa tingkat I kelas B tahun ajaran 2018/2019. Pemilihan sampel didasarkan pada pertimbangan pentingnya kemampuan penalaran pada calon guru dan pentingnya penerapan pembelajaran yang menyenangkan di lingkungan mahasiswa tingkat I yang sedang dalam masa peralihan.

Data dalam penelitian ini diperoleh dengan menggunakan instrumen tes kemampuan penalaran matematis yang sama untuk setiap tes. Data yang diperoleh terdiri dari dari data hasil 
pretest, posttest, dan gain ternormalisasi untuk melihat kualitas peningkatan kemampuan penalaran matematis. Data yang diperoleh kemudian dianalisis secara deskriptif dan inferensi. Pengujian secara inferensi dilakukan dengan bantuan SPSS 16.0, dimulai dengan uji normalitas data, kemudian uji-t satu sampel. Adapun kategori gain ternormalisasi yang digunakan dalam penelitian ini yaitu menurut Hake (dalam Sundayana, 2016:151) sebagai berikut:

Tabel 1

\section{Interpretasi Gain Ternormalisasi yang Dimodifikasi}

\begin{tabular}{|c|c|}
\hline $\begin{array}{c}\text { Nilai Gain } \\
\text { Ternormalisai }\end{array}$ & Interpretasi \\
\hline$-1.00 \leq \mathrm{g}<0$ & Terjadi Penurunan \\
\hline $\mathrm{g}=0.00$ & Tetap \\
\hline $0.00<\mathrm{g}<0.30$ & Rendah \\
\hline $0.30 \leq \mathrm{g}<0.70$ & Sedang \\
\hline $0.70 \leq \mathrm{g} \leq 1.00$ & Tinggi \\
\hline
\end{tabular}

Selanjutnya untuk mengetahui efektivitas digunakan kategori menurut Riduwan (2013: 22) sebagai berikut:

Tabel 2

\section{Kriteria Persentase Efektivitas}

\begin{tabular}{|c|c|}
\hline Skala Interval & Keterangan \\
\hline $0 \%-20 \%$ & Tidak Efektif \\
\hline $21 \%-40 \%$ & Kurang Efektif \\
\hline $41 \%-60 \%$ & Netral/Cukup \\
\hline $61 \%-80 \%$ & Efektif \\
\hline $81 \%-100 \%$ & Sangat Efektif \\
\hline
\end{tabular}

\section{HASIL DAN PEMBAHASAN}

Analisis data dalam penelitian ini bertujuan untuk mengetahui efektifitas penggunaan pembelajaran model snowball throwing terhadap peningkatan kemampuan penalaran matematis mahasiswa. Adapun data yang diperoleh dari hasil pretest, posttest, dan gain ternormalisasi secara umum disajikan pada tabel berikut:
Tabel 3

Data Statistik Skor Kemampuan Penalaran Matematis

\begin{tabular}{|c|c|c|c|}
\hline \multirow{2}{*}{ Variabel } & Data & \multicolumn{2}{|c|}{ Kelas Eksperimen } \\
\cline { 3 - 4 } & Statistik & Pretest & Posttest \\
\hline \multirow{4}{*}{$\begin{array}{c}\text { Kemampuan } \\
\text { Penalaran } \\
\text { Matematis }\end{array}$} & $\mathrm{N}$ & 28 & 28 \\
\cline { 2 - 4 } & $\mathrm{X}_{\text {maks }}$ & 0.80 & 4.00 \\
\cline { 2 - 4 } & $\mathrm{X}_{\min }$ & 0.20 & 2.80 \\
\cline { 2 - 4 } & $\bar{x}$ & 0.40 & 3.41 \\
\cline { 2 - 4 } & $\mathrm{SD}$ & 0.18 & 0.31 \\
\hline
\end{tabular}

Berdasarkan data pada tabel 3 diketahui bahwa nilai rerata pretest yaitu sebesar 0.40 , sedangkan rerata posttest sebesar 3.41. Secara deskriptif tampak bahwa nilai pretest mengalami peningkatan yang relatif tinggi pada saat posttest yaitu sebesar 3.01. Untuk lebih jelasnya, perhatikan data gain ternormalisasi pada tabel berikut:

Tabel 4

Data Hasil Gain Ternormalisasi

\begin{tabular}{|c|c|c|}
\hline Variabel & $\begin{array}{c}\text { Data } \\
\text { Statistik }\end{array}$ & $\begin{array}{c}\text { Gain } \\
\text { Ternormalisasi }\end{array}$ \\
\hline \multirow{4}{*}{$\begin{array}{c}\text { Kemampuan } \\
\text { Penalaran } \\
\text { Matematis }\end{array}$} & $\mathrm{N}$ & 28 \\
\cline { 2 - 3 } & $\mathrm{X}_{\text {maks }}$ & 1.00 \\
\cline { 2 - 3 } & $\mathrm{X}_{\min }$ & 0.67 \\
\cline { 2 - 3 } & $\bar{x}$ & 0.84 \\
\cline { 2 - 3 } & $\mathrm{SD}$ & 0.08 \\
\hline
\end{tabular}

Berdasarkan data gain ternormalsisasi pada tabel 4 , diketahui bahwa dari mahasiswa sebanyak 28 orang, diperoleh $X_{\text {maks }}=1.00$ dan $X_{\min }=$ 0.67 . Data tersebut mendeskripsikan bahwa kemampuan penalaraan matematis mahasiswa mengalami peningkatan pada kategori sedang dan tinggi. Sedangkan secara keseluruhan, dapat diketahui bahwa rerata nilai gain ternormalisasi sebesar 0.84 atau $84 \%$. Nilai peningkatan tersebut termasuk ke dalam kategori tinggi. Jika dilihat dari efektifitasnya pada tabel 2 , maka nilai $84 \%$ termasuk ke dalam kriteria sangat efektif. Berdasarkan data tersebut dapat disimpulkan secara deskriptif bahwa model pembelajaran snowball throwing sangat efektif terhadap peningkatan kemampuan penalaran matematis. Selanjutnya untuk 
keperluan pengujian hipotesis maka dilakukan uji statistik inferensi terhadap data gain ternormalisasi yang diawali dengan uji normalitas. Adapun hasil uji normalitas dengan menggunakan uji Shapiro-wilk yaitu sebagai berikut:

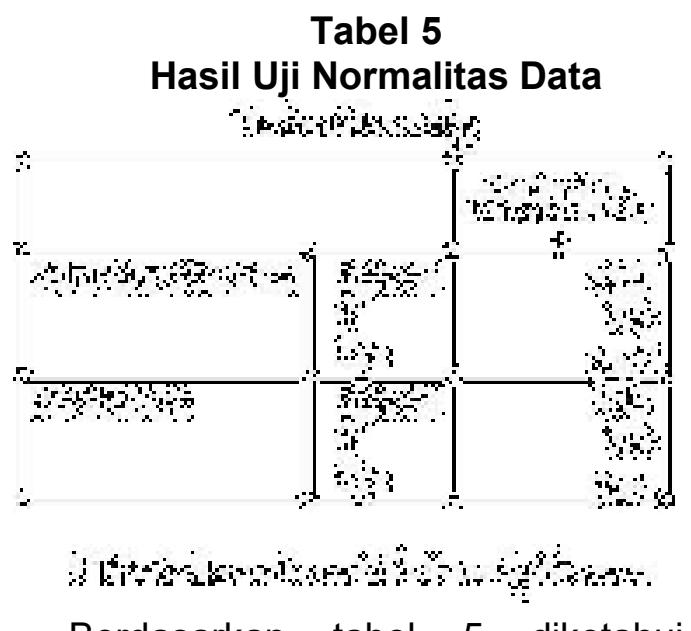

Berdasarkan tabel 5 diketahui bahwa nilai Sig. $=0.547$. Nilai tersebut lebih besar dari $\alpha=0.05$, atau Sig. $>\alpha$ sehingga dapat diketahui bahwa data berdistribusi normal. Selanjutnya dilakukan uji-t untuk menguji hipotesis, dengan hasil sebagai berikut:

Tabel 6

Hasil Uji-t

One-Sample Test

\begin{tabular}{|c|c|c|c|}
\hline & & & $\begin{array}{c}\text { data_gain } \\
\text { ternormalisas } \\
i\end{array}$ \\
\hline \multirow[t]{5}{*}{ Test Value $=0.7$} & \multicolumn{2}{|l|}{$t$} & 8.646 \\
\hline & \multicolumn{2}{|l|}{ df } & 27 \\
\hline & \multicolumn{2}{|l|}{ Sig. (2-tailed) } & .000 \\
\hline & \multicolumn{2}{|l|}{ Mean Difference } & .13821 \\
\hline & $\begin{array}{l}95 \% \text { Confidence Interval } \\
\text { of the Difference }\end{array}$ & $\begin{array}{l}\text { Lower } \\
\text { Upper }\end{array}$ & $\begin{array}{l}.1054 \\
.1710\end{array}$ \\
\hline
\end{tabular}

Berdasarkan tabel 6 diketahui bahwa untuk nilai test value sebesar 0.7 (batas minimal nilai peningkatan dengan interpretasi tinggi) didapat nilai Sig (2-tailed) sebesar 0.000. Dengan $\alpha$ $=0.05$ maka Sig (2-tailed) $=0.000<\alpha=$ 0.05 yang berarti bahwa Ho ditolak atau Ha diterima. Dengan demikian dapat disimpulkan bahwa penggunaan pembelajaran model snowball throwing sangat efektif meningkatkan kemampuan penalaran matematis mahasiswa (po $\geq 70 \%$ ).

Hasil penelitian yang didapat yaitu penggunaan pembelajaran model snowball throwing sangat efektif meningkatkan kemampuan penalaran matematis mahasiswa sejalan dengan pengamatan peneliti selama penelitian berlangsung. Pada awal pertemuan, mahasiswa cenderung masih kebingungan dan pembelajaran masih belum tertib. Terlebih pembelajaran dimulai pagi hari. Mahasiswa tampak masih ada yang mengantuk dan belum memahami dengan benar pembelajaran dengan snowball throwing. Selain itu, ketua kelompok yang dipilih pun masih tampak kebingungan dalam menjelaskan materi kepada teman sekelompoknya.

Pada pertemuan kedua, suasana belajar sudah jauh lebih tertib dan menyenangkan. Tidak ada lagi mahasiswa yang mengantuk. Hal ini karena mahasiswa mulai fokus terhadap materi yang dipelajari. Selain itu, pada saat mahasiswa mulai jenuh dengan pembelajaran, ada kegiatan melempar kertas bola salju yang membuat mahasiswa bisa sejenak melakukan pergerakan atau olah tubuh dan bersenda gurau. Kendala pada pertemuan kedua yaitu cukup sulitnya menertibkan kembali mahasiswa setelah kegiatan lempar kertas bola salju. Hal ini mengakibatkan waktu menjadi kurang efektif selama beberapa menit.

Pada pertemuan selanjutnya, pembelajaran berjalan sesuai dengan rencana. Suasana belajar sangat tertib. Para ketua kelompok yang terpilih sudah bisa menyampaikan kembali materi kepada teman sekelompoknya dengan baik. Para mahasiswa pun tampak aktif mengembangkan materi yang sudah dijelaskan oleh ketua kelompok. Mereka berlomba membuat pertanyaan yang baik untuk nantinya dijawab oleh kelompok yang lain. Selain itu, kegiatan lempar kertas bola salju pun tampak tertib. Mahasiswa 
langsung menertibkan diri sendiri sejenak setelah kegiatan melempar selesai, dan langsung kembali fokus pada bola kertas yang mereka dapatkan dari kelompok yang lain dan mulai bekerja untuk menyelesaikan persoalan.

Peningkatan aktivitas belajar ke arah yang lebih baik juga sejalan dengan peningkatan nilai yang didapat dari pretest ke posttest. Kualitas tersebut dapat dilihat dari perolehan nilai gain ternormalisasi dimana dari 28 mahasiswa, hanya terdapat 2 orang mahasiswa yang peningkatannya masuk ke dalam kategori sedang. Adapun 26 orang lainnya mengalami peningkatan dengan kategori tinggi.

\section{KESIMPULAN}

Berdasarkan hasil penelitian dan pembahasan yang sudah diuraikan sebelumnya, maka kesimpulan dari penelitian ini yaitu bahwa penggunaan pembelajaran model snowball throwing sangat efektif meningkatkan kemampuan penalaran matematis mahasiswa ( $p o \geq 70 \%$ ).

Adapun saran yang diajukan peneliti berdasarkan kesimpulan penelitian yaitu sebagai berikut:

1. Pembelajaran snowball throwing direkomendasikan untuk menjadi alternatif pembelajaran dalam meningkatkan kemampuan penalaran matematis mahasiswa.

2. Pada penelitian ini yang dikaji hanya kemampuan penalaran matematis, direkomendasikan pada penelitian lainnya untuk mengkaji penerapan pembelajaran snowball throwing dalam pencapaian kemampuan berpikir matematik lainnya.

3. Sampel pada penelitian ini diambil tanpa memperhatikan kategori kemampuan awal pada mahasiswa, direkomendasikan pada penelitian lainnya untuk mengkaji pencapaian kemampuan komunikasi matematis mahasiswa berdasarkan kategori kemampuan awal mahasiswa baik kategori tinggi, sedang, dan rendah.

\section{REFERENSI}

Agus Suprijono. (2011). Cooperative Learning. Yogyakarta : Pustaka Pelajar.

Badan Standar Nasional Pendidikan, 2006. Standar isi. Jakarta: BSNP.

Hendriana, $H$. dan Soemarmo, $U$. (2014).Penilaian Pembelajaran Matematika. Bandung: RefikaAditama.

Huda, M. (2011). Model-model Pengajaran dan Pembelajaran. Yogyakarta: Pustaka Belajar

Kusmawati, A. (2013). Perbandingan Kemampuan Penalaran Matematika Siswa Antara yang Mendapatkan Model Pembelajaran CLIS (Children Learning In Science) denngan Model Pembelajaran Konvensional.Skripsi STKIP Garut: Tidakditerbitkan.

Purbowo, Mashuri \& Hendikawati. 2012. Kefektifan Pembelajaran Snowball Throwing Berbantuan Lembar Kegiatan Siswa. Unnes Journal of Mathematics Education. 1 (1) 20-25

Rasyid, M., \& Side, S. (2011). Pengaruh Penerapan Pembelajaran Snowball Throwing terhadap Hasil Belajar Vol 2, No. 1 (2017)

Riduwan. (2013). Skala Pengukuran Variabel-Variabel Penelitian. Bandung: Alfabeta

Rosnawati, R. (2011). "Kemampuan penalaran matematika siswa SMP Indonesia pada TIMSS 2011". Prosiding Seminar Nasional Penelitian, Pendidikan dan Penerapan MIPA

Ruseffendi, H. E. T. (2006). Pengantar kepada Membantu Guru Mengembangkan Kompetensinya dalam Pengajaran Matematika untuk Meningkatkan CBSA. Bandung: Tarsito. 
Sagala, S. (2011). Konsep dan Makna Pembelajaran. Bandung: Alfabeta.

Shadiq, Fadjar. 2004. Pemecahan Masalah, Penalaran dan Komunikasi. Yogyakarta: PPPG Matematika.

Soedjadi, R. (2000). Kiat Pendidikan Matematika di Indonesia. Jakarta: Dirjen Dikti Depdinas.Turmudi. (2008). Landasan Filsafat dan Teori Pembelajaran Matematika Siswa dalam Pelajaran Matematika. Disertasi doktor pada PPS IKIP Bandung: Tidak dipublikasikan.

Sumarmo, U., 2013. Kumpulan makalah: Berpikir dan disposisi matematis serta pembelajarannya. Bandung: Jurusan Pendidikan Matematika, FPMIPA UPI.

Sundayana, R. (2013). Statistika Penelitian Pendidikan. Garut: STKIP Garut Press.

Suparno \& Yunus, M. 2006. Keterampilan Dasar Menulis. Jakarta: Universitas Terbuka

Wahyudin, 2008. Pembelajaran \& Model-model pembelajaran: Pelengkap untuk meningkatkan kompetensi pedagogis para guru dan calon guru profesional. Bandung: Mandiri.

Wahyudin. (2008). Pembelajaran dan Model-Model Pembelajaran.

Bandung: UPI

\section{RIWAYAT HIDUP PENULIS}

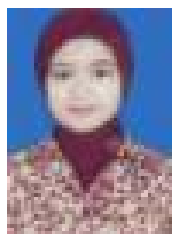

Irena Puji Luritawaty,

M. Pd. Lahir di

Tangerang, 30 April 1988.

Staf pengajar di prodi pendidikan matematika di

Institut Pendidikan Indonesia Garut. Studi S1 Pendidikan Matematika Sekolah Tinggi Keguruan dan Ilmu Pendidikan Garut, lulus tahun 2010; S2 Pendidikan Matematika Universitas Pendidikan Indonesia, lulus tahun 2014 